\title{
Genetic variability in Brazilian wheat cultivars assessed by microsatellite markers
}

\author{
Ivan Schuster ${ }^{1,2}$, Elisa Serra Negra Vieira ${ }^{1}$, Glacy Jaqueline da Silva ${ }^{2}$, Francisco de Assis Franco ${ }^{1}$ \\ and Volmir Sérgio Marchioro ${ }^{1}$ \\ ${ }^{1}$ Cooperativa Central de Pesquisa Agricola, Cascavel, PR, Brazil. \\ ${ }^{2}$ Departamento de Ciências Biológicas, Universidade Paranaense, Cascavel, PR, Brazil.
}

\begin{abstract}
Wheat (Triticum aestivum) is one of the most important food staples in the south of Brazil. Understanding genetic variability among the assortment of Brazilian wheat is important for breeding. The aim of this work was to molecularly characterize the thirty-six wheat cultivars recommended for various regions of Brazil, and to assess mutual genetic distances, through the use of microsatellite markers. Twenty three polymorphic microsatellite markers (PMM) delineated all 36 of the samples, revealing a total of 74 simple sequence repeat (SSR) alleles, i.e. an average of 3.2 alleles per locus. Polymorphic information content (PIC value) calculated to assess the informativeness of each marker ranged from 0.20 to 0.79 , with a mean of 0.49 . Genetic distances among the 36 cultivars ranged from 0.10 (between cultivars Ocepar 18 and BRS 207) to 0.88 (between cultivars CD 101 and Fudancep 46), the mean distance being 0.48 . Twelve groups were obtained by using the unweighted pair-group method with arithmetic means analysis (UPGMA), and thirteen through the Tocher method. Both methods produced similar clusters, with one to thirteen cultivars per group. The results indicate that these tools may be used to protect intellectual property and for breeding and selection programs.
\end{abstract}

Key words: Triticum aestivum, germplasm, cultivar characterization, cluster analysis, molecular markers.

Received: August 13, 2008; Accepted: January 30, 2009.

Although Brazil is not as yet self-sufficient in wheat (Triticum aestivum) production and depends on importation to supply its domestic requirements, wheat has already become an important crop, especially in the south, in the states of Paraná and Rio Grande do Sul. As a winter crop, it is an income-option for farmers who grow soybean or corn in the summer. In 2007, Brazil produced 3.82 million tons of wheat on 1.82 million ha of land, $90 \%$ of which was in Rio Grande do Sul and Paraná (Conab, 2008).

Although several types of molecular markers have been employed to evaluate genetic diversity in wheat, such as random amplified polymorphic DNA (RAPD) (Joshi and Nguyen, 1993), restriction fragment-length polymorphism (RFLP) (Siedler et al, 1994, Kim and Ward, 2000), amplified fragment-length polymorphism (AFLP) (Barret and Kidwell, 1998, Burkhamer et al., 1998), sequence tagged-site (STS) (Chen et al., 1994) and inter-simple sequence repeat (ISSR) (Devos and Galley, 1992; Nagaoka and Ogihara, 1997), microsatellite markers have been suggested as the most informative method for this type of analysis (Röder et al., 1998a, 1998b). Since they are multi-

Send correspondence to Ivan Schuster. Cooperativa Central de Pesquisa Agrícola, Rua Marechal Deodoro 4048, 85.811-160 Bairro Claudete, Cascavel, PR, Brazil. E-mail: ivan@ coodetec.com.br. allelic, chromosome-specific and well distributed in the genome, microsatellite markers have already been used with wheat for selecting specific genes (Peng et al., 1999; Börner et al., 2000), for identifying quantitative trait loci (QTLs) (Parker et al., 1998) and for molecular markerassisted selection (Korzun et al., 1998, Huang et al., 2000). In species other than wheat, microsatellite markers have also been used to ascertain the genetic purity of seeds (Schuster et al., 2004), as well as a means of protecting intellectual property (Bertini et al., 2006; Schuster et al., 2006). However, in order to use microsatellite markers as cultivar-identification tools for the protection of intellectual-property, for example, it is necessary to know the allelic frequency of informative loci in order to calculate random identity-exclusion probability (Schuster et al., 2006).

In this work, we evaluated genetic diversity within a representative compilation of the germplasm of Brazilian wheat, in order to assess allelic frequencies in an informative set of microsatellite loci, thereby permitting a more accurate identification of varieties of Brazilian wheat. Thirty-six cultivars, developed at various research centers, both private and public, were used (Table 1).

DNA samples were extracted from a thirty-seed bulk of each cultivar, obtained from the Coodetec germplasm 
Table 1 - Genealogy and suppliers of wheat cultivars used in the genetic diversity study.

\begin{tabular}{|c|c|c|c|}
\hline Supplier & Nature & Cultivar & Genealogy \\
\hline \multirow[t]{8}{*}{ EMBRAPA } & Public & BRS 179 & BR 35/PF 8596/3/ PF 772003*2/PF 813//PF 83899 \\
\hline & & BRS 207 & SERI 82/PF 813 \\
\hline & & BRS 208 & CPAC89118/3/BR23//CEP19/PF85490 \\
\hline & & BRS 210 & CPAC89118/3/BR23//CEP19/PF85490 \\
\hline & & BRS 220 & EMBRAPA16/TB108 \\
\hline & & BRS 229 & EMB $27 * 3 / / \mathrm{BR} 35 / \mathrm{BUCK}$ PONCHO \\
\hline & & BRS Camboatá & HULHANEGRA/CNT 7//AMIGO/CNT 7 \\
\hline & & Embrapa 42 & LAP 689/MS 7936 \\
\hline \multirow[t]{16}{*}{ COODETEC } & Cooperative & CD 101 & AU/UP301//OCEPAR 12-MAITACA \\
\hline & & CD 102 & IAC5/ALDAN"S"//CEP 7780 \\
\hline & & CD 103 & PG 864/OCEPAR 14 \\
\hline & & CD 104 & PFAU'S'/IAPAR 17 \\
\hline & & CD 105 & PFAU"S"/2*OCEPAR 14//IAPAR 41 \\
\hline & & CD 106 & PG 864/GENARO \\
\hline & & CD 107 & COCORAQUE*2/BR 23//BR 35 \\
\hline & & CD 108 & TAM200/TURACO \\
\hline & & CD 109 & MUNIA/BAGULA \\
\hline & & CD 110 & ANAHUAC 75/EMBRAPA 27 \\
\hline & & CD 111 & EMBRAPA 27/OCEPAR 18//ANAHUAC 75 \\
\hline & & CD 112 & IOC 905/pg 877 \\
\hline & & CD 113 & EMBRAPA 27/OC 946 \\
\hline & & CD 114 & PF 89232/OC 938 \\
\hline & & CD 115 & OC $926 / / \mathrm{BTU} / \mathrm{pg} 868$ \\
\hline & & Ocepar 18 & KVZ/BUHO 'S'//KAL/BB \\
\hline \multirow[t]{2}{*}{ IAPAR } & Public & IPR 85 & IAPAR 30/BR18 \\
\hline & & Iapar 78 & VEE'S/'BOW'S \\
\hline \multirow[t]{4}{*}{ FUNDACEP } & Fundation & Fundacep 30 & BR 32/CEP 21//CNO 79 \\
\hline & & Fundacep 46 & CEP 88132/pg 876/3/BR 34//CRDN \\
\hline & & Funadcep 50 & CEP 88132/pg 876/3/BR 34//CRDN \\
\hline & & Fundacep 52 & CEP 88132/pg 876/3/BR 34//CRDN \\
\hline \multirow[t]{5}{*}{ OR Sementes } & Private & Avante & PF89232/2* OR1 \\
\hline & & Abalone & ORL92299/3/ORL92171//EMB16/OR1/4/RUBI \\
\hline & & Ônix 5 & CEP 24/RUBI'S' \\
\hline & & Vanguarda & OR 1/ORL92177//EMB16/OR1 \\
\hline & & Safira & PF 9099/OR 1//GRANITO \\
\hline Public domain & - & Frontana & FRONTEIRA/MENTANA \\
\hline
\end{tabular}

collection. DNA extraction from the seeds was undertaken according to the protocol described by McDonald et al. (1994), but with certain adjustments. Thirty seeds from each cultivar were ground utilizing a MA 048 mill (Marconi), and $50 \mathrm{mg}$ sub-samples of flour collected therefrom. DNA concentration was determined spectrophotometrically (Sambrook et al., 1989).

Microsatellite-loci amplification was performed by using DNA samples in a $20 \mu \mathrm{L}$ volume containing $12.5 \mathrm{mM}$
Tris- $\mathrm{HCl}$ ( $\mathrm{pH} 8.3$ ), $62.5 \mathrm{mM} \mathrm{KCl}, 2.5 \mathrm{mM} \mathrm{MgCl}_{2}, 125 \mu \mathrm{M}$ of each of the deoxynucleotides (dATP, dTTP, dGTP e $\mathrm{dCTP}), 0.4 \mu \mathrm{M}$ of each primer, one unit of Taq DNA polymerase enzyme and $75 \mathrm{ng}$ of DNA. Amplification was achieved with a 7-min initial step at $94{ }^{\circ} \mathrm{C}$ followed by thirty cycles of $1 \mathrm{~min}$ at $94{ }^{\circ} \mathrm{C}, 1 \mathrm{~min}$ at $55^{\circ} \mathrm{C}, 2 \mathrm{~min}$ at $72{ }^{\circ} \mathrm{C}$ and finally a $7-$ min step at $72{ }^{\circ} \mathrm{C}$ after the $30^{\text {th }}$ cycle. Amplified fragments were separated and revealed on $7 \%$ polyacrylamide denaturing gels stained with silver-nitrate. 
The polymorphic information content (PIC) of each microsatellite locus was evaluated through allelic frequency:

$$
P I C=1-\sum_{j=1}^{n} p_{i j}^{2}
$$

where $p_{\mathrm{ij}}$ represents the frequency from the $j^{\text {th }}$ allele to the $i^{\text {th }}$ primer (Anderson et al., 1993).

Genetic relationships among accessions were evaluated through a dissimilarity matrix, using the complement of a similarity index for co-dominant and multi-allelic data with the aid of GENES software (Cruz, 2006).

From dissimilarity assessments, cultivars were clustered by means of the Tocher optimization method, the hierarchical unweighted pair-group method with arithmetic means analysis (UPGMA), Ward's method and complete and single linkage methods. A cophenetic correlation analysis between the original dissimilarity matrix and the dissimilarity matrices obtained from dendograms was carried out to define the hierarchical clustering method which best represented the original data. Clustering analysis using hierarchical methods was undertaken with STATISTICA software (StatSoft Inc Tulsa, OK, USA) and Tocher optimization clustering analysis with GENES software (Cruz, 2006).

Besides eight unmapped loci (Table 2), 12 genome-A loci, 13 genome-B loci and 10 genome-D loci were evaluated. From these 43 loci, 23 presented polymorphisms among the 36 wheat cultivars analyzed (54\%). In these 23 polymorphic loci, the numbers of alleles observed per locus ranged from two to five, making a total of 74 alleles, with a mean of 3.2 alleles per locus. PIC values calculated in order to estimate the informativeness of each polymorphic locus, varied from 0.20 to 0.79 , with a mean of 0.49 (Table 2).

The variabilities obtained in $\mathrm{A}, \mathrm{B}$ and $\mathrm{D}$ genomes were similar. In genome A, six out of the twelve loci evaluated were polymorphic $(50 \%)$, with 21 alleles ( 3.5 alleles per locus), whereas, in genome $B$, seven out of thirteen loci were polymorphic (54\%), with 18 alleles (2.6 alleles per locus), and in genome D, six out of ten SSR loci were polymorphic (60\%), with s17 alleles (2.8 alleles per locus).

Among the eight unmapped SSR loci, four were polymorphic (50\%), with 18 alleles ( 4.5 alleles per locus). PIC values were $0.54 ; 0.49 ; 0.38$ and 0.60 for $\mathrm{A}, \mathrm{B}$ and $\mathrm{D}$ genomes, as well as the unmapped loci, respectively.

Genetic distances among the cultivars ranged from 0.10 , between Ocepar 18 and BRS 207, to 0.88 between CD 101 and Fundacep 46, with a mean distance of 0.48 . The highest frequencies of genetic distance occurring between 0.40 and 0.60 (Figure S1, in supplementary material).

Table 1 sets forth the genealogy of the 36 cultivars. A group of three cultivars (Fundacep 46, 50 and 52) and another pair of cultivars (BRS208 and 210) could not be distinguished by genealogy. There were 74 different parents in the genealogy of these wheat cultivars, of which a few par- ticipated in more than one genealogy. From the 630 parentage coefficients $(\mathrm{CP})$ possible between these 36 cultivars, only 24 were different from zero. Therefore, it was not possible to correctly group these cultivars by genealogy alone.

By using molecular markers, it was possible to distinguish all thirty-six cultivars and group these by genetic similarity. We used four hierarchical methods. Cophenetic correlations obtained between the original dissimilarity matrix and matrices from dendograms were $67 \%, 42 \%$, $46 \%$ and $53 \%$ for the UPGMA, Ward's, complete-linkage and single-linkage methods, respectively. Due to its higher degree of cophenetic correlation, the UPGMA approach (Figure 1) was chosen for graphical representation of cultivar clusters.

Furthermore, clusters obtained by UPGMA, when a cutoff is at a distance of 0.42 , paralleled those obtained by the Tocher optimization method (Table 3). Only two of the 36 cultivars presented some clustering divergence between methods. Cultivar CD 110 was clustered in group 1 by UPGMA and in group 7 by Tocher. Cultivar CD 104, clustered in group 2 by UPGMA, remained isolated in group 12 by Tocher. The other 34 cultivars were clustered similarly by both methods, thus indicating a high degree of clustering consistency.

The 13 clusters formed revealed high genetic diversity among the wheat cultivars. Group 1, consisting of 13 cultivars by the Tocher method and 14 by the UPGMA, contained cultivars from all origins. The three Fundacep cultivars with the same genealogy (Fundacep 46, 50 and 52) were closely clustered. The two cultivars from Embrapa, with the same genealogy (BRS208 and 210),

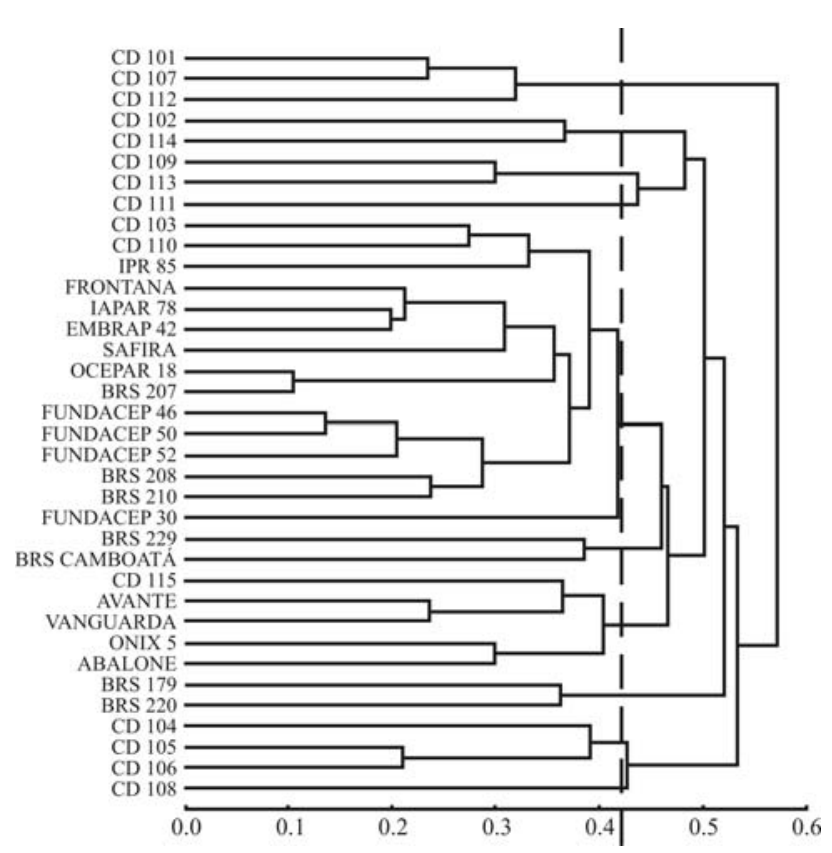

Figure 1 - Clustering assessment obtained by UPGMA based on dissimilarity measurements of thirty-six Brazilian wheat cultivars. The hatched line indicates the cutoff for cluster formation. 
Table 2 - Microsatellite markers used in assessment of genetic diversity of Brazilian wheat cultivars.

\begin{tabular}{|c|c|c|c|c|c|}
\hline Locus & $\begin{array}{l}\text { Chromosome location } \\
(\mathrm{cM}-\mathrm{GL})^{\#}\end{array}$ & $\begin{array}{c}\text { Number of } \\
\text { alleles }\end{array}$ & Frequency of alleles & Representative alleles ${ }^{\S}$ & PIC \\
\hline Xgwm 136 & $3.9-1 \mathrm{~A}$ & 5 & $0.12 ; 0.31 ; 0.26 ; 0,24 ; 0.07$ & CD 115; CD 114; FRONTANA; CD 112; ABALONE & 0.76 \\
\hline Xgwm 164 & $40.5-1 \mathrm{~A}$ & 4 & $0.22 ; 0.17 ; 0.55 ; 0.06$ & CD 112; CD 105; CD 104; CD 111 & 0.61 \\
\hline Xgwm 135 & $55.2-1 \mathrm{~A}$ & 3 & $0.18 ; 0.29 ; 0.53$ & CD 113; CD 102; CD 104 & 0.60 \\
\hline Xgwm 403 & 64.4-1B & 1 & 1.00 & All & - \\
\hline Xgwm 140 & 102.1-1B & 1 & 1.00 & All & - \\
\hline Xgwm 337 & $39.5-1 \mathrm{D}$ & 4 & $0.06 ; 0.10 ; 0.61 ; 0.23$ & BRS 208; CD 114; CD 105; CD 104 & 0.56 \\
\hline Xgwm 232 & $130.4-1 \mathrm{D}$ & 2 & $0.11 ; 0.89$ & CD 102; AVANTE & 0.20 \\
\hline Xgwm 359 & $54.4-2 \mathrm{~A}$ & 1 & 1.00 & All & - \\
\hline Xgwm 265 & $112.3-2 \mathrm{~A}$ & 1 & 1.00 & All & - \\
\hline Xgwm 257 & $12.3-2 \mathrm{~B}$ & 2 & $0.20 ; 0.80$ & CD 112; CD 104 & 0.32 \\
\hline Xgwm 261 & $?-2 \mathrm{D}$ & 2 & $0.39 ; 0.61$ & CD 104; IPR 85 & 0.48 \\
\hline Xgwm 102 & $36.0-2 \mathrm{D}$ & 3 & $0.03 ; 0.10 ; 0.87$ & CD 114; CD 105; CD 103 & 0.23 \\
\hline Xgwm 301 & $78.8-2 \mathrm{D}$ & 1 & 1.00 & All & - \\
\hline Xgwm 369 & $18.8-3 \mathrm{~A}$ & 1 & 1.00 & All & - \\
\hline Xgwm 32 & $49.5-3 \mathrm{~A}$ & 3 & $0.11 ; 0.86 ; 0.03$ & CD 111; CD 104 ; ONIX 5 & 0.25 \\
\hline Xgwm 285 & $65.3-3 \mathrm{~B}$ & 2 & $0.54 ; 0.46$ & FRONTANA; CD 104 & 0.50 \\
\hline Xgwm 108 & $96.1-3 \mathrm{~B}$ & 3 & $0.13 ; 016 ; 0.71$ & CD 105; CD 108; CD 103 & 0.46 \\
\hline Xgwm 299 & $122.6-3 B$ & 1 & 1.00 & All & - \\
\hline Xgwm 161 & $15.7-3 \mathrm{D}$ & 3 & $0.06 ; 0.26 ; 0.68$ & BRS 179; CD 115; CD 111 & 0.47 \\
\hline Xgwm 456 & $52.9-3 \mathrm{D}$ & 1 & 1.00 & All & - \\
\hline Xgwm 4 & $16.1-4 \mathrm{~A}$ & 1 & 1.00 & All & - \\
\hline Xgwm 160 & $77.1-4 \mathrm{~A}$ & 3 & $0.22 ; 0.57 ; 0.20$ & CD 105; BRS 210; CD 115 & 0.58 \\
\hline Xgwm 165 & $27.1-4 \mathrm{~B}$ & 2 & $0.85 ; 0.15$ & CD 105; CD 104 & 0.25 \\
\hline Xgwm 149 & $30.5-4 \mathrm{~B}$ & 2 & $0.65 ; 0.34$ & CD 104; FUNDACEP 52 & 0.45 \\
\hline Xgwm 194 & $95.4-4 \mathrm{D}$ & 3 & $0.80 ; 0.17 ; 0.03$ & CD 104; CD 115; CD 102 & 0.32 \\
\hline Xgwm 234 & $1.8-5 \mathrm{~B}$ & 1 & 1.00 & All & - \\
\hline Xgwm 213 & $32.5-5 \mathrm{~B}$ & 1 & 1.00 & All & - \\
\hline Xgwm 212 & $107.0-5 \mathrm{D}$ & 1 & 1.00 & All & - \\
\hline Xgwm 459 & $5.0-6 \mathrm{~A}$ & 1 & 1.00 & All & - \\
\hline Xgwm 219 & $62.6-6 \mathrm{~B}$ & 3 & $0.61 ; 0.19 ; 0.20$ & CD 204; CD 208; CD 205 & 0.79 \\
\hline Xgwm 233 & $6.6-7 \mathrm{~A}$ & 3 & $0.13 ; 0.71 ; 0.16$ & CD 110; CD 104; CD 111 & 0.46 \\
\hline Xgwm 276 & $85.6-7 \mathrm{~A}$ & 1 & 1.00 & All & - \\
\hline Xgwm 43 & $33.7-7 \mathrm{~B}$ & 1 & 1.00 & All & - \\
\hline Xgwm 302 & $57.2-7 \mathrm{~B}$ & 1 & 1.00 & All & - \\
\hline Xgwm 44 & 43.9-7D & 4 & $0.16 ; 0.13 ; 0.52 ; 0.16$ & CD 112; CD 114; BRS 229; ÔNIX 5 & 0.65 \\
\hline Xgwm 247 & $*$ & 5 & $0.03 ; 0.03 ; 0.50 ; 0.22 ; 0.22$ & CD 105; CD 108; CD 104; AVANTE; BRS 220 & 0.65 \\
\hline Xgwm 304 & $*$ & 4 & $0.06 ; 0.06 ; 0.76 ; 0.12$ & FUNDACEP 30; CD 112; BRS 229; CD 104 & 0.45 \\
\hline Xgwm 332 & $*$ & 1 & 1.00 & All & - \\
\hline Xgwm 155 & * & 4 & $0.05 ; 0.39 ; 0.53 ; 0.03$ & FUNDACEP 50; CD 114; CD 104; CD 109 & 0.57 \\
\hline Xgwm 372 & * & 5 & $0.37 ; 0.12 ; 0.29 ; 0.06 ; 0.16$ & CD 111; ABALONE; BRS CD 115; CD 105 & 0.73 \\
\hline Xgwm 126 & $*$ & 1 & 1.00 & All & - \\
\hline Xgwm 132 & * & 1 & 1.00 & All & - \\
\hline Xgwm 268 & $*$ & 1 & 1.00 & All & - \\
\hline
\end{tabular}

\#Location of markers in wheat genetic map (Song et al., 2005). *Unmapped loci. ?Unknown position. ${ }^{\S}$ Representative cultivars of alleles in each locus. Each cultivar represents the allele, whose frequency is shown in the previous column, in the same order. Primer sequences can be obtained in http://wheat.pw.usda.gov/cgi-bin/graingenes/browse.cgi?class = marker. 
Table 3 - Grouping of 36 wheat cultivars assessed from genetic distances obtained by microsatellite marker data, using Tocher's and the UPGMA methods.

\begin{tabular}{lll}
\hline Group & Tocher & UPGMA \\
\hline 1 & BRS 210; BRS 208; FUNDACEP 52; FUNDACEP 50; & BRS 210; BRS 208; FUNDACEP 52; FUNDACEP 50; \\
& FUNDACEP 46; OCEPAR18; BRS 207; EMBRAP42; SAFIRA; & FUNDACEP 46; OCEPAR18; BRS 207; EMBRAP42; SAFIRA; \\
2 & IAPAR 78; FRONTANA; CD 103; IIPR 85 & IAPAR 78; FRONTANA; CD 103; IIPR 85; CD 110 \\
3 & CD 105; CD 106 & CD 105; CD 106; CD 104 \\
4 & CD 101; CD 107; CD 112 & CD 101; CD 107; CD 112 \\
5 & AVANTE; VANGUARDA; CD 115 & AVANTE; VANGUARDA; CD 115 \\
6 & CD 109; CD 113 & CD 109; CD 113 \\
7 & ONIX 5; ABALONE & ONIX 5; ABALONE \\
8 & CD 111; CD 110 & CD 111 \\
9 & BRS 179; BRS 220 & BRS 179; BRS 220 \\
10 & CD 102; CD 114 & CD 102; CD 114 \\
11 & BRS 229; BRS CAMBOATÁ & BRS 229; BRS CAMBOATÁ \\
12 & CDNDACEP 30 & FUNDACEP 30 \\
13 & CD 108 & - \\
\hline
\end{tabular}

were also clustered within this group (Figure 1). Of the 18 Coodetec germplasm cultivars, 14 were clustered either in groups containing exclusively Coodetec cultivars or were not clustered together with any other cultivar (groups 2,3 , $5,7,9,12$ and 13) at all. Even so, there was high genetic variability among these cultivars themselves, seeing that seven different groups were obtained.

Similarly, there was a tendency for OR cultivars to form unique groups. Group 6 contained OR seeds exclusively, and group 4 contained only one cultivar from another origin. Of the eight Embrapa cultivars evaluated, four were clustered in group 1 along with others, the remaining four forming two exclusive groups, 8 and 10 .

Table 2 shows the frequencies of all alleles revealed in polyacrylamide gels. Since fragment size characterization is not completely reproducible in this system, a representative cultivar was placed for each allele, so as to enable recognizing alleles identical to those observed in this work when using these same cultivars in future studies. This is important, especially in cases where it is necessary to define the genetic identity of a certain cultivar. On knowing allele frequency, identity and exclusion probabilities can then be calculated (Schuster et al., 2006).

Results obtained with polymorphic primers in this work were consistent with those reported by other authors. Akkaya and Buyukunal-Bal (2004) obtained PIC values ranging from 0.36 to 0.87 , with a mean of 0.68 , when evaluating 19 SSR highly polymorphic loci in 11 wheat cultivars. Ahmed (2002) observed from two to eight alleles per locus, with a mean of 3.6, in 13 wheat genotypes of diverse origin analyzed with 43 SSR markers. We observed a mean of 3.2 alleles per locus within a range from two to five, and for PIC values ranging from 0.20 to 0.79 , a mean of 0.49 .
The microsatellite profiles, characterized with 23 pairs of polymorphic markers, showed that the loci employed delineated all the 36 cultivars. Thus, these markers can be used to define the genetic profile of each cultivar. These genetic profiles, or fingerprints, may be useful in the protection of cultivars, for ensuring genetic purity and for generating further information to underpin breeding programs (Bertini et al., 2006). In addition and due to the allelic frequencies obtained in each locus, it is possible to acquire genetic identity and exclusion probabilities in cases involving the protection of intellectual-property (Schuster et al., 2006).

To date, no evaluation of Brazilian wheat germplasm by using microsatellite markers has been undertaken. The markers applied here were found to be polymorphic, with a potential for germplasm characterization. With this in mind, these should be chosen according to their informativeness and measured by PIC magnitude values.

The results obtained in this study revealed that there is significant genetic divergence among Brazilian wheat cultivars, so that breeding programs can exploit expressive genetic variability by using only adapted germplasm. This observation can be set forth based on molecular data as much as genealogy. However, genealogy cannot group cultivars by genetic similarity, whereas molecular data can do so. Also, our results revealed that cultivars may be grouped according to origin.

On evaluating 23 Brazilian wheat cultivars, Bertan et al. (2006) arrived at similar results. In order to separate aluminum-susceptible and -resistant cultivars, these authors obtained four large groups of cultivars, most of which were delineated according to the supplier. Vieira et al. (2007), on using AFLP markers to evaluate genetic diversity in an- 
other set of 19 Brazilian wheat cultivars, found that out of 11 cultivars from EMBRAPA, seven did not group closely with any cultivar in the same group, independent of the origin.

Results obtained in this work show that a highly variable wheat germplasm has been adapted for use in Brazil. Therefore, it is possible to widely exploit this vast variability in segregating populations within breeding programs, by simply using only adapted cultivars. The results also provide information on the informativeness of those microsatellite loci and allelic frequencies that may be applied in evaluating still further the wheat germplasm used in Brazil, as well as in protecting intellectual property.

\section{Acknowledgments}

Special thanks go to Coodetec and Unipar for financial support.

\section{References}

Ahmed M (2002) Assessment of genomic diversity among wheat genotypes as determined by simple sequence repeats. Genome 45:646-651.

Akkaya MS and Buyukunal-Bal EB (2004) Assessment of genetic variation of bread wheat varieties using microsatellite markers. Euphytica 35:179-185.

Anderson JA, Churchill GA, Autrique JE, Tanksley SD and Sorrells ME (1993) Optimizing parental selection for genetic linkage maps. Genome 36:181-186.

Barret BA and Kidwell KK (1998) AFLP-based genetic diversity assessment among wheat cultivars from the Pacific Northwest. Crop Sci 38:1261-1271.

Bertan I, Carvalho FIF, Oliveira AC, Silva JAG, Benin G, Vieira EA, Silva GO, Hartwig I, Valério IP and Finatto T (2006) Dissimilaridade genética entre genótipos de trigo avaliados em cultivo hidropônico sob estresse por alumínio. Bragantia 65:55-63 (Abstract in English).

Bertini CHCM, Schuster I, Sedyiama T, Barros EG and Moreira MA (2006) Characterization and genetic diversity analysis of cotton cultivar using microsatellite. Genet Mol Biol 29:321-329.

Börner A, Röder MS, Unger O and Meinel A (2000) The detection and molecular mapping of a major gene for non-specific adult plant disease resistance against stripe rust (Puccinia stiiformins) in wheat. Theor Appl Genet 100:1095-1099.

Burkhamer RL, Lanning SP, Martens RJ, Martin JM and Talbert LE (1998) Predicting progeny variance from parental divergence in hard red spring wheat. Crop Sci 38:243-248.

Chen HB, Martin JM, Lavin M and Talbert LE (1994) Genetic diversity in hard red spring wheat based on sequence-taggedsite PCR markers. Crop Sci 34:1628-1632.

Cruz CD (2006) Programa Genes: Biometria. Editora UFV, Viçosa, $382 \mathrm{pp}$.

Devos KM and Galley MD (1992) The use of random amplified polymorphic DNA markers in wheat. Theor Appl Genet 84:567-572.
Huang XQ, Hsam SLK, Zeller FJ, Wenzel G and Mohler V (2000) Molecular mapping of wheat powdery mildew resistance gene Pm24 and marker validation for molecular breeding. Theor Appl Genet 101:407-414.

Joshi CP and Nguyen HT (1993) RAPD (random amplified polymorphic DNA) analysis based intervarietal genetic relationships among hexaploid wheats. Plant Sci 93:95-103.

Kim HS and Ward RW (2000) Patterns of RFLP-based genetic diversity in germplasms pools of common wheat whith different geographical or breeding program origins. Euphytica 115:197-208.

Korzun V, Röder MS, Ganal MW, Worland AJ and Law CN (1998) Genetic analysis of the dwarfing gene (Rht8) in wheat. Part I. Molecular mapping of Rht 8 on the short arm of chromosome 2D of bread wheat (Triticum aestivum L.). Theor Appl Genet 96:1104-1109.

McDonald MB, Elliot LJ and Sweeney PM (1994) DNA extraction from dry seeds for RAPD analyses in varietal identification studies. Seed Sci Technol 22:171-176.

Nagaoka T and Ogihara Y (1997) Applicability of inter-simple sequence repeat polymorphisms in wheat for use as DNA markers in comparison to RFLP and RAPD markers. Theor Appl Genet 94:597-602.

Parker GD, Chalmers KJ, Rathjen AJ and Langride P (1998) Mapping loci associated with flour colour in wheat (Triticum aestivum L.). Theor Appl Genet 97:238-245.

Peng JH, Fahima T, Röder MS, Li YC, Dahan A, Grama A, Ronin YI, Korol AB and Nevo E (1999) Microsatellite tagging of the stripe-rust resistance gene $\mathrm{YrH} 52$ derived from wild emmer wheat, Triticum dicoccoides, and suggestive negative crossover interference on chromosome 1B. Theor Appl Genet 98:862-872.

Röder MS, Korzum V, Gil BS and Ganal MW (1998a) The physical mapping of microsatellite markers in wheat. Genome 41:278-283.

Röder MS, Korzum V, Wendehake K, Plashke J, Tixier MH, Leroy P and Ganal MW (1998b) A microsatellite map of wheat. Genetics 149:2007-2023.

Sambrook J, Fritsch EF and Maniatis T (1989) Molecular Cloning: Laboratory Manual. 2nd edition. CSHL, Cold Spring Harbor.

Schuster I, Queiroz VT, Teixeira AI, Barros EG and Moreira MA (2004) Determinação da pureza varietal de sementes de soja com auxílio de marcadores moleculares microssatélites. Pesq Agropec Bras 39:247-253 (Abstract in English).

Schuster I, Vieira ESN and Padilha L (2006) Marcadores moleculares no pós-melhoramento. In: Caixeta BE (ed) Marcadores Moleculares. Jard, Viçosa, pp 206-230.

Siedler H, Messmer MM, Schachermeyr GM, Winzeler H, Winzeler M and Keller B (1994) Genetic diversity in European wheat and spelt breeding material based on RFLP data. Theor Appl Genet 88:994-1003.

Song QJ, Shi JR, Singh S, Fickus EW, Costa JM, Lewis J, Gill BS, Ward R and Creagan PB (2005) Development and mapping of microsatellite (SSR) markers in wheat. Theor Appl Genet 110:550-560. 
Vieira EA, Carvalho FIF, Bertan I, Kopp MM, Zimmer PD, Benin G, Silva JAG, Hartwig I, Malone G and Oliveira AC (2007) Association between genetic distances in wheat (Triticum aestivum L.) as estimated by AFLP and morphological markers. Genet Mol Biol 30:392-399.

\section{Internet Resources}

CONAB, Acompanhamento da safra brasileira: grãos: oitavo levantamento, maio 2008/Companhia Nacional de Abastecimento. Conab, Brasília, 2008. http://www.conab.gov.br. (March 6, 2008).

\section{Supplementary Material}

The following online material is available for this article:

- Figure S1 - Frequency distribution of genetic distances.

This material is available as part of the online article from http://www.scielo.br/gmb.

Associate Editor: Everaldo Gonçalves de Barros

License information: This is an open-access article distributed under the terms of the Creative Commons Attribution License, which permits unrestricted use, distribution, and reproduction in any medium, provided the original work is properly cited. 


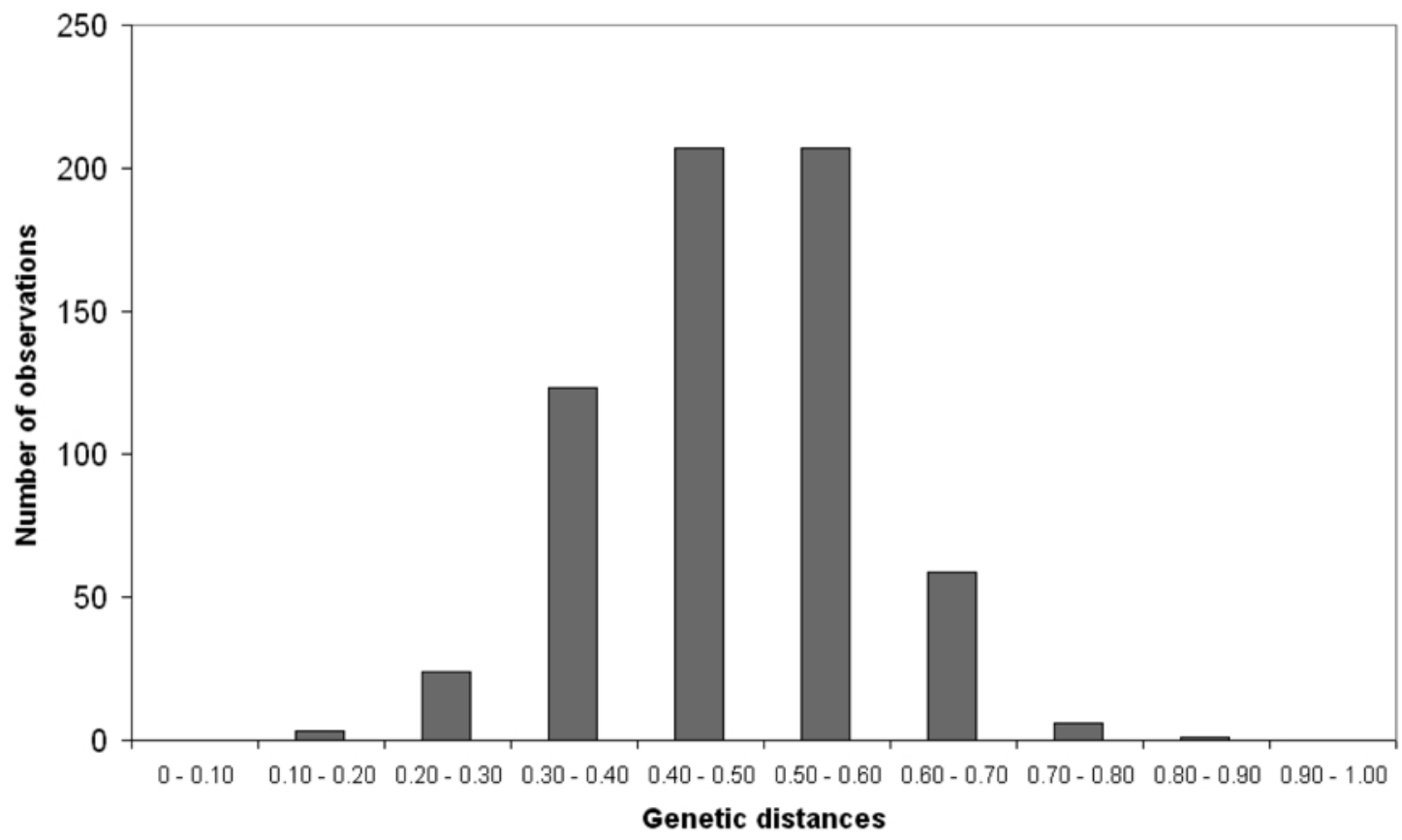

Figure S1 - Frequency distribution of genetic distances obtained in thirty-six wheat cultivars with twenty-three SSR polymorphic loci. 